\title{
PERFORMANCE OF MODELS FOR RADIOCARBON DATING OF GROUNDWATER: AN APPRAISAL USING SELECTED IRISH AQUIFERS
}

\author{
D Gallagher $^{1} \bullet \mathrm{E} \mathrm{J} \mathrm{McGee}^{1} \bullet \mathrm{R} \mathrm{M} \mathrm{Kalin}^{2} \bullet \mathrm{P}^{\mathrm{I}}$ Mitchell $^{1}$
}

\begin{abstract}
Appropriate management strategies are essential for the protection and maintenance of groundwater resources. It is therefore important that aquifers are understood in terms of hydraulics, recharge, and yield potential, and that the vulnerability of aquifers to surface pollution is evaluated. A range of aquifer types were examined in this study, and water samples were analyzed for the radiocarbon content of the total dissolved inorganic carbon (TDIC), stable isotopes, and a suite of chemical and physical parameters. The data were input to a selection of models for the estimation of the initial activity of the TDIC, and groundwater ages were calculated. Eight commonly used models were comparatively assessed in the study. The Tamers, Mook, and IAEA models gave anomalous ages, probably because of their inability to correct for solid phase isotopic exchange in aquifers. The Pearson, F\&G, Evans, Eichinger, and Mass Balance models produced results in broad agreement.

The study shows that contrary to popular belief, there are sources of ancient groundwater in Ireland. Of the 19 sampling stations, two boreholes yielded waters with age estimates of greater than 10,000 BP. Water samples from a further six sites returned ages of between around 800 and 4000 BP. In contrast to borehole samples, spring wells yielded water of consistently young ages, demonstrating rapid recharge and flow mechanisms. Samples from several spring wells produced negative ages, indicating the presence of anthropogenic ${ }^{14} \mathrm{C}$. The findings demonstrate the potential for contamination of springs by surface runoff, while sources of greater age generally offer a greater degree of protection from surface pollution.
\end{abstract}

\section{INTRODUCTION}

\section{The Importance of Groundwater Resources}

Traditionally, groundwater from shallow wells supplied most rural farms and villages in Ireland. Many of these groundwater sources were abandoned with the arrival of mains water, which currently supplies over $90 \%$ of the population. Mains supplies are largely surface water, stored in reservoirs, and requiring chemical treatment prior to distribution. In contrast, most groundwaters emerge from the source as potable waters, devoid of bacterial pathogens and not requiring chemical treatment. The excellent quality and abundance of our groundwaters has led to the development of a sizeable industry that now produces bottled water for export world-wide. However, few data exist concerning the duration of groundwater storage, and no previous work on groundwater dating has been carried out in Ireland.

In this work we sample two distinct aquifer systems and carry out detailed radiometric and chemical analyses. We describe and apply hydrological models to estimate the age of groundwaters based on chemical and isotopic data. A comparative evaluation of these models is then carried out using the data, and we run a sensitivity analysis on the models examining output differences resulting from variations in important analytical parameters.

\section{${ }^{14} \mathrm{C}$ Groundwater Dating}

Radiocarbon age calculations are based upon the assumption that the initial activity of the material to be dated was $100 \%$ of modern $\mathrm{CO}_{2}$ activity $(100 \mathrm{pMC})$. This assumption is generally good for material of organic origin (wood, peat, bone, etc.). However, the ${ }^{14} \mathrm{C}$ age of groundwaters is that of the total dissolved inorganic carbon (TDIC) which, more often than not, has an initial activity far from 100 pMC. The TDIC has two main sources: carbon derived from the soil zone, and less active

\footnotetext{
${ }^{1}$ Radiocarbon Laboratory, Department of Experimental Physics, University College Dublin, Dublin 4, Ireland. Corresponding author email: Edward.Mcgee@ucd.ie.

${ }^{2}$ Environmental Engineering Research Centre, Department of Civil Engineering, The Queen's University of Belfast, Belfast BT7 1NN, Northern Ireland
} 
(or even "dead") carbon derived from solid carbonate in the soil and aquifer matrix. The initial activity, $A_{\mathrm{o}}$, is derived from a combination of the two sources and is defined as the ${ }^{14} \mathrm{C}$ content after all chemical and isotopic processes have taken place and before any decay (Wigley 1975). In order to estimate $A_{\mathrm{o}}$, the use of a model is required.

Active $\mathrm{CO}_{2}$ may reach the water table in several ways, including dissolution of $\mathrm{CO}_{2}$ from root respiration, decay of organic matter and direct diffusion from the atmosphere through the unsaturated zone. Under normal geochemical conditions, the main source is soil $\mathrm{CO}_{2}$, which dissolves largely without reaction; carbonic acid is formed only in small quantities:

$$
\mathrm{CO}_{2}(\mathrm{~g})+\mathrm{H}_{2} \mathrm{O} \leftrightarrow \mathrm{CO}_{2}(\mathrm{aq})+\mathrm{H}_{2} \mathrm{CO}_{3}
$$

Since the concentration of $\mathrm{H}_{2} \mathrm{CO}_{3}$ is difficult to measure, the right-hand side of the above equation is often grouped in a composite parameter (Lloyd and Heathcote 1985), which is effectively the total dissolved $\mathrm{CO}_{2}$ and is defined by:

$$
\left[\mathrm{H}_{2} \mathrm{CO}_{3}^{*}\right]=\left[\mathrm{CO}_{2}(\mathrm{aq})\right]+\left[\mathrm{H}_{2} \mathrm{CO}_{3}\right]
$$

Where groundwater is in contact with solid carbonate deposits, dissolution of the carbonates takes place through a reaction with carbonic acid. The reactions with calcite, the most common carbonate, can be considered typical. Two reaction schemes of importance when dating groundwater are:

1. the reaction of water with soil zone $\mathrm{CO}_{2}$ in the absence of calcite followed by the solution achieving equilibrium with calcite out of contact with the gaseous $\mathrm{CO}_{2}$ reservoir, and

2. the three-phase equilibrium between solution, soil zone $\mathrm{CO}_{2}$, and soil zone calcite.

Scheme 1 describes the dissolution of $\mathrm{CO}_{2}$ under open system conditions (i.e., the partial pressure of $\mathrm{CO}_{2}$ is constant), followed by the dissolution of calcite under closed system conditions (i.e., out of contact with $\mathrm{CO}_{2}$ gas), which can be represented by Equation 3. This reaction scheme is described as closed system dissolution, although the complete reaction is a two-stage process involving both open and closed steps.

$$
\mathrm{H}_{2} \mathrm{CO}_{3}{ }^{*}+\mathrm{CaCO}_{3} \leftrightarrow \mathrm{Ca}^{2+}+2 \mathrm{HCO}_{3}^{-}
$$

Scheme 2 is represented by Equation 4 and is described as open system dissolution. Most natural waters fall somewhere between the two schemes.

$$
\mathrm{H}_{2} \mathrm{O}+\mathrm{CO}_{2}+\mathrm{CaCO}_{3} \leftrightarrow \mathrm{Ca}^{2+}+2 \mathrm{HCO}_{3}^{-}
$$

Models attempt to account for the dilution of ${ }^{14} \mathrm{C}$ by less active carbon and for isotopic exchange reactions which may take place between the different carbon-bearing chemical species. Reactions 1 , 2, and 3 (summarized in a more complete form in Equation 5) describe how $\mathrm{CO}_{2}$, produced by the decomposition of organic material in the soil or by root respiration in the unsaturated zone, can dissolve carbonates, thus diluting the ${ }^{14} \mathrm{C}$ content of the TDIC.

$$
(a+0.5 b) \mathrm{CO}_{2}+\mathrm{H}_{2} \mathrm{O}+0.5 b \mathrm{CaCO}_{3} \leftrightarrow 0.5 b \mathrm{Ca}^{2+}+b \mathrm{HCO}_{3}{ }^{-}+a \mathrm{H}_{2} \mathrm{CO}_{3}{ }^{*}
$$


$a$ and $b$ are the concentrations of the dissolved $\mathrm{CO}_{2}$ and $\mathrm{HCO}_{3}{ }^{-}$, respectively. This process is by far the predominant source of dissolved inorganic carbon in groundwater, however, other sources may have to be taken into account in specific situations (Mook 1980).

Isotopic exchange reactions, while not affecting the average dissolved carbon content of the water, can change the ${ }^{14} \mathrm{C}$ content of the dissolved bicarbonate. Isotopic exchange between gaseous $\mathrm{CO}_{2}$ and dissolved bicarbonate $\left(\mathrm{HCO}_{3}{ }^{-}\right)$in the unsaturated region increases the ${ }^{14} \mathrm{C}$ content of the TDIC:

$$
{ }^{14} \mathrm{CO}_{2}+\mathrm{H}^{12} \mathrm{CO}_{3}^{-} \rightarrow{ }^{12} \mathrm{CO}_{2}+\mathrm{H}^{14} \mathrm{CO}_{3}
$$

On the other hand, isotopic exchange between the bicarbonate and solid carbonate phase decreases the ${ }^{14} \mathrm{C}$ content:

$$
\mathrm{H}^{14} \mathrm{CO}_{3}^{-}+\mathrm{Ca}^{12} \mathrm{CO}_{3} \rightarrow \mathrm{H}^{12} \mathrm{CO}_{3}^{-}+\mathrm{Ca}^{14} \mathrm{CO}_{3}
$$

\section{SAMPLING AND METHODOLOGY}

\section{Site Geology}

Northeastern Ireland has a very compact and diverse range of solid geology, Quaternary deposits, and soil types (Figure 1). The sites studied in this project were selected from two distinct geological contexts: the Permo-Triassic Sandstones and the Cretaceous Chalk. A Lower Palaeozoic sequence of Ordovician and Silurian Turbidites and Greywackes (Kalin and Roberts 1997) dips underneath the Lagan Valley at approximately $10^{\circ}$ to the northwest (Figure 2). Unconformably resting over this basement are the Permian and Triassic sequences, which are important aquifers contributing water to the supplies of Belfast and the highly populated northeastern part of Ulster. Boreholes from aquifers within these Permian and Triassic sequences were sampled and investigated during the course of this study.

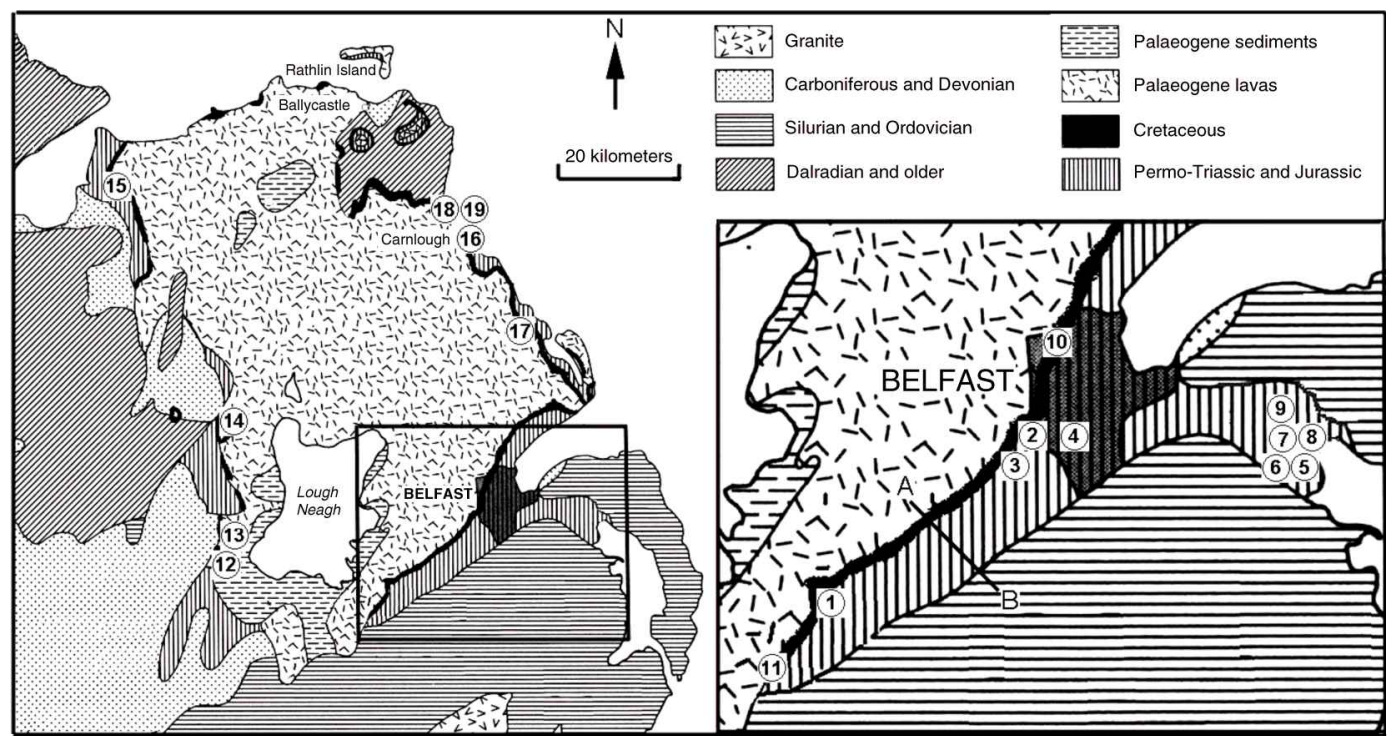

Figure 1 Geological map of northeastern Ireland showing sampling locations (adapted from Robins 1996) 


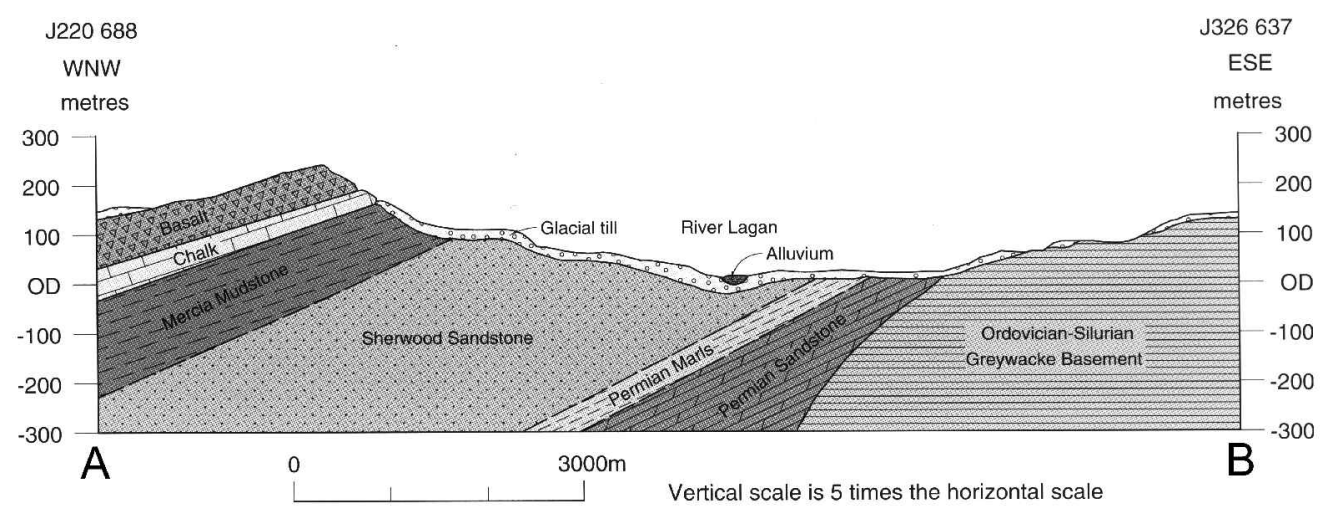

Figure 2 Diagrammatic geological section across the Lagan Valley (adapted from Robins 1996). Refer to Figure 1 for the approximate locations of $\mathrm{A}$ and $\mathrm{B}$.

It is known that the Permian Sandstone, which reaches a thickness of 50-70 m beneath the Lagan Valley, has a typical transmissivity of $100 \mathrm{~m}^{2} \mathrm{~d}^{-1}$ and storativity (coefficient of storage) of $2 \times 10^{-4}$ (Bennett 1975). The Triassic Sherwood Sandstone is 270-300 m thick and is separated from the Permian Sandstone by 50-60 m of Permian marls. The Sherwood Sandstone exhibits transmissivity values of typically $130 \mathrm{~m}^{2} \mathrm{~d}^{-1}$ with storativity of $2 \times 10^{-3}$ (Bennett 1975). Above the Sherwood Sandstone lies the Mercia Mudstone. The Triassic aquifer is almost entirely concealed by till, whereas the Sherwood Sandstone is mostly concealed by late-glacial sand, gravel and riverine alluvium, with till below. Due to the low hydraulic conductivities measured for the glacial till, it might be assumed that this source is responsible for only a small component of the total recharge (Kalin and Roberts 1997). However, recharge mechanisms and sources of groundwater in the aquifers have not been investigated in detail.

Cretaceous Chalk (known as the Ulster White Limestone Formation) occurs along the northeast coast and in a number of inland regions around Lough Neagh. The chalk is mostly concealed by overlying Palaeogene basalt lavas (the hexagonally fractured Giants Causeway is a famous outcrop). Numerous springs emerge from the base of the chalk at its contact with the relatively impermeable underlying strata. Boreholes that penetrate the chalk through the basalt are relatively few in number because of the considerable thickness of the basalt, although two such locations were sampled as part of this study. Recharge to the chalk occurs predominately from surface water by point recharge via sinking streams at the basalt-chalk contact. Recharge via the basalt is said to be a minor component to the overall water budget in the chalk (Barnes and Worden 1998; Barnes 1999). Groundwater samples from springs in the chalk aquifers were also examined during the course of this work.

\section{Sampling}

Between 25 and $75 \mathrm{~L}$ of water, depending on the total dissolved inorganic carbon (TDIC) content, were used in each ${ }^{14} \mathrm{C}$ analysis. Samples were taken and stored in clear plastic $25 \mathrm{~L}$ carboys with airtight caps to avoid evaporation and exchange with carbon in the atmosphere. Before filling, the carboys were thoroughly rinsed using the water source that was to be sampled. They were then completely filled, with care taken to minimize exposure of the samples to the atmosphere and to exclude air when sealing the samples. Where possible, the carboys were filled from a hose placed in the bottom of the container, and the container was allowed to overflow until the initial content was entirely 
flushed. Additional water samples were taken at each site for complementary analyses: $2.5 \mathrm{~L}$ for chemical analysis, $0.5 \mathrm{~L}$ for $\delta^{13} \mathrm{C}$ analysis, and $0.5 \mathrm{~L}$ for stable isotope analysis. The samples were sealed and transported back to the laboratory for chemical treatment.

The first step in the chemical treatment requires the precipitation of carbonates dissolved in the water samples. Carbonate-free $\mathrm{NaOH}$ was added to adjust the $\mathrm{pH}$ of the water sample to approximately 12 . Once the $\mathrm{NaOH}$ was well mixed through the sample and the $\mathrm{pH}$ correct, excess $\mathrm{BaCl}_{2} \cdot 2 \mathrm{H}_{2} \mathrm{O}$ was added to precipitate the TDIC. The carboy was sealed tightly and the contents agitated to ensure complete mixing. The $\mathrm{BaCO}_{3}$ precipitate was allowed to settle for several hours before it was transferred to a round-bottomed reaction flask. This was fitted to a vacuum line and evacuated in preparation for reaction with $\mathrm{HCl}$ for $\mathrm{CO}_{2}$ production and subsequent benzene synthesis (O’Donnell 1997).

\section{Liquid Scintillation}

The ${ }^{14} \mathrm{C}$ activity of the synthesized benzene was measured using liquid scintillation counting (LSC) on a Packard Tri-Carb $2770 \mathrm{TR} / \mathrm{SL}$ in low ${ }^{40} \mathrm{~K}$, borosilicate glass vials with brass lids, Teflon liners and indium foil $(0.25 \mathrm{~mm}$ thick) seals. A scintillation cocktail containing $3.0 \mathrm{mg}$ of butyl-PBD and $3.0 \mathrm{mg}$ of bis-MSB per gram of benzene was used. Reagent blank benzene samples were synthesized from a high purity, ancient calcium carbonate. The contemporary standard was synthesized from the NBS oxalic acid ${ }^{14} \mathrm{C}$ standard (SRM-4990). Vials were stored in a freezer for at least three weeks before counting.

\section{Hydrochemical Models}

Hydrochemical models have been developed to correct for aspects of the mixing and isotopic reactions involving the TDIC in groundwater. Table 1 lists and briefly describes the models assessed in this project. The parameters required to calculate the output of each model and some of the limitations of the models are also presented. The mathematical form and a more detailed description of each model can be found in Fontes (1992). Table 2 lists the notation assigned to each of the model input parameters.

Where possible, we measured the values of the parameters used in the models applied in this study for each individual groundwater system under investigation. However, it was not feasible to measure all the necessary parameter values. In such cases, we used estimates based on previous studies (Table 3).

\section{RESULTS AND DISCUSSION}

Table 4 presents the values for the $\delta^{13} \mathrm{C}$ measured with respect to PDB on water samples for each of the sites under investigation. Data for water samples from the Permo-Triassic aquifers are relatively consistent and range from -14.7 to $-16.6 \%$. A wider range of $\delta^{13} \mathrm{C}$ values $(-7.9$ to $-19.9 \%$ o was observed for samples from the Cretaceous aquifer. Water from the deep Aughrimderg borehole exhibited the high $\delta^{13} \mathrm{C}$ value of $-7.9 \%$, which suggests a large degree of either mixing or isotopic exchange between the TDIC and the chalk. The corresponding pMC estimate of $7.79 \%$ was the lowest of all the studied locations. A second deep borehole through the basalt to the chalk (Clendinnings) similarly yielded water of low pMC value $(9.17 \%)$. In contrast to these boreholes, springs along the basalt/chalk interface yielded water with $\delta^{13} \mathrm{C}$ values ranging between -15.6 and $-19.9 \%$ and had associated higher pMC values (ranging between 74.03 and $94.72 \%$ ). $\delta^{13} \mathrm{C}$ and pMC measurements from the Ligoniel site show excellent agreement for duplicate analyses, and demonstrate the precision of our techniques. 
Table 1 Summary of a selection of the hydrochemical models used in ${ }^{14} \mathrm{C}$ groundwater dating

\begin{tabular}{|c|c|c|c|}
\hline $\begin{array}{l}\text { Model } \\
\text { (references below) }\end{array}$ & $\begin{array}{l}\text { Reactions accounted for by } \\
\text { model }\end{array}$ & $\begin{array}{c}\text { Input } \\
\text { parameters }^{\mathrm{a}}\end{array}$ & Limitations \\
\hline Vogel $^{\mathrm{b}}$ & $\begin{array}{l}\text { Empirical estimation to account } \\
\text { for mixing and exchange pro- } \\
\text { cesses }\end{array}$ & - & $\begin{array}{l}\text { Only useful for soil } \\
\text { waters and shallow } \\
\text { groundwaters in tem- } \\
\text { perate climates. }\end{array}$ \\
\hline Tamers $^{\mathrm{c}}$ & $\begin{array}{l}\text { Dissolution-mixing reaction } \\
\text { (Eqn. 5) based on the chemical } \\
\text { balance }\end{array}$ & $\begin{array}{c}a, b \\
A_{\mathrm{g}}, A_{\mathrm{c}}\end{array}$ & $\begin{array}{l}\text { Does not take into ac- } \\
\text { count any isotopic ex- } \\
\text { change reactions }\end{array}$ \\
\hline Pearson $^{\mathrm{d}}$ & $\begin{array}{l}\text { Dissolution-mixing reaction } \\
\text { (Eqn. 5) based on the isotopic } \\
\text { balance }\end{array}$ & $\begin{array}{l}\delta_{\mathrm{T}}, \delta_{\mathrm{c}}, \delta_{\mathrm{g}} \\
\quad A_{\mathrm{g}}, A_{\mathrm{c}}\end{array}$ & $\begin{array}{l}\text { Only accounts for in- } \\
\text { complete isotopic ex- } \\
\text { change processes }\end{array}$ \\
\hline Mook $^{\mathrm{e}}$ & $\begin{array}{l}\text { Dissolution-mixing reaction (us- } \\
\text { ing Tamers) and isotopic ex- } \\
\text { change with gas phase (Eqn. 6) }\end{array}$ & $\begin{array}{c}a, b \\
A_{\mathrm{g}}, A_{\mathrm{c}} \\
\delta_{\mathrm{T}}, \delta_{\mathrm{c}}, \delta_{\mathrm{g}} \\
\varepsilon_{\mathrm{gb}}\end{array}$ & $\begin{array}{l}\text { Does not take into ac- } \\
\text { count isotopic ex- } \\
\text { change with solid } \\
\text { phase carbonate }\end{array}$ \\
\hline$F \& G^{f}$ & $\begin{array}{l}\text { Dissolution-mixing reaction (us- } \\
\text { ing Tamers) and isotopic ex- } \\
\text { change with gas (Eqn. 6) or solid } \\
\text { phase (Eqn. 7) }\end{array}$ & $\begin{array}{c}a, b \\
A_{\mathrm{g}}, A_{\mathrm{c}} \\
\delta_{\mathrm{T}}, \delta_{\mathrm{c}}, \delta_{\mathrm{g}} \\
\varepsilon_{\mathrm{gb}}, \varepsilon_{\mathrm{bc}} \\
\end{array}$ & $\begin{array}{l}\text { Complete isotope ex- } \\
\text { change in open-sys- } \\
\text { tem conditions cannot } \\
\text { be derived }\end{array}$ \\
\hline IAEA $^{g}$ & $\begin{array}{l}\text { Dissolution-mixing reaction (us- } \\
\text { ing Pearson) plus isotopic ex- } \\
\text { change with gas phase (Eqn. 6) }\end{array}$ & $\begin{array}{l}A_{\mathrm{g}}, A_{\mathrm{c}} \\
\delta_{\mathrm{T}}, \delta_{\mathrm{c}}, \delta_{\mathrm{g}} \\
\quad \varepsilon_{\mathrm{gb}}\end{array}$ & $\begin{array}{l}\text { Does not take into ac- } \\
\text { count isotopic ex- } \\
\text { change with solid } \\
\text { phase carbonate }\end{array}$ \\
\hline Evans $^{\text {h }}$ & $\begin{array}{l}\text { Dissolution-precipitation reac- } \\
\text { tion (Eqn. 5) with fractionation } \\
\text { due to precipitation processes } \\
\text { considered }\end{array}$ & $\delta_{\mathrm{T}},{ }_{\varepsilon_{\mathrm{c}}^{\mathrm{g}}}^{A_{\mathrm{c}}}, \delta_{\mathrm{g}}$ & $\begin{array}{l}\text { Does not take into ac- } \\
\text { count isotopic ex- } \\
\text { change with gas phase }\end{array}$ \\
\hline Eichinger $^{\mathrm{i}}$ & $\begin{array}{l}\text { Dissolution-mixing reaction (us- } \\
\text { ing Tamers) considering partial } \\
\text { isotope exchange with solid } \\
\text { phase carbonates }\end{array}$ & $\begin{array}{c}a, b \\
A_{\mathrm{g}}, A_{\mathrm{c}} \\
\delta_{\mathrm{T}}, \delta_{\mathrm{c}}, \delta_{\mathrm{g}}, \delta_{\mathrm{a}} \\
\varepsilon_{\mathrm{gb}}, \varepsilon_{\mathrm{cb}}\end{array}$ & $\begin{array}{l}\text { Cannot correct for iso- } \\
\text { topic exchange with } \\
\text { the gas phase }\end{array}$ \\
\hline Mass balance ${ }^{j}$ & $\begin{array}{l}\text { All important reactions of inor- } \\
\text { ganic carbon applying mass } \\
\text { transfer calculations }\end{array}$ & $\begin{array}{l}\text { Extensive chemistry } \\
\text { data including all } \\
\text { above parameters }\end{array}$ & $\begin{array}{l}\text { Dependent on level of } \\
\text { understanding of } \\
\text { aquifer chemistry }\end{array}$ \\
\hline
\end{tabular}

aSee Table 2 for explanation of notation.

${ }^{b}$ Vogel and Ehhalt (1963); cTamers (1967); dingerson and Pearson (1964); e Mook (1980); fFontes and Garnier (1979); Fontes

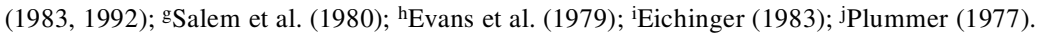

All of the Permo-Triassic sites were boreholes, and water samples from these locations gave pMC values which were higher than the two deeper boreholes to the Cretaceous aquifers $(45.72-80.17 \%)$, but generally lower than values for springs along the basalt/chalk interface.

The isotopic data of Table 4 and chemical data of Table 5 were input to the models previously described in order to estimate the initial activity of the TDIC $\left(A_{\mathrm{o}}\right)$. Model output results are presented in Table 6 . In order to compare the overall performance of the models, a mean initial activity value for each of the models was calculated by pooling data for all of the Permo-Triassic sites. The procedure was then repeated for model predictions by pooling data for all Cretaceous sites. Figure 3 graphically presents these results.

The Mook and IAEA models are clearly demonstrated to grossly overpredict the initial activity of the TDIC. These models are specifically designed to account for isotopic exchange with the gas 
Table 2 Parameters used in calculating the hydrochemical models for ${ }^{14} \mathrm{C}$ groundwater dating

\begin{tabular}{cl}
\hline Notation & Explanation \\
\hline $\mathrm{a}, \mathrm{b}$ & Concentration of the total dissolved $\mathrm{CO}_{2}\left(\mathrm{H}_{2} \mathrm{CO}_{3}{ }^{*}\right)$ and $\mathrm{HCO}_{3}{ }^{-}$, respectively \\
$A_{\mathrm{g}}, A_{\mathrm{c}}$ & ${ }^{14} \mathrm{C}$ activity of the soil $\mathrm{CO}_{2}$ gas and solid carbonates, respectively \\
$\delta_{\mathrm{T}}, \delta_{\mathrm{c}}, \delta_{\mathrm{g}}, \delta_{\mathrm{a}}$ & $\begin{array}{l}{ }^{13} \mathrm{C} \text { content of the TDIC, solid carbonate, soil } \mathrm{CO}_{2} \text { and total dissolved } \mathrm{CO}_{2} \text { re- } \\
\text { spectively (\%o relative to the PDB standard) }\end{array}$ \\
$\varepsilon_{\mathrm{gb}}, \varepsilon_{\mathrm{cb}}, \varepsilon_{\mathrm{bc}}{ }^{\mathrm{a}} \quad \begin{array}{l}\text { Stable isotope enrichment factor between the soil } \mathrm{CO}_{2} \text { gas and } \mathrm{HCO}_{3}{ }^{-} \text {, the solid } \\
\text { carbonates relative to } \mathrm{HCO}_{3}{ }^{-} \text {and } \mathrm{HCO}_{3}{ }^{-} \text {relative to solid carbonates respectively }\end{array}$ \\
\hline
\end{tabular}

${ }^{a}$ See Mook (1980) for mathematical form for enrichment factors; note, $\varepsilon_{\mathrm{bc}} \approx-\varepsilon_{\mathrm{cb}}$.

Table 3 Assumed parameter values used in the hydrochemical models

\begin{tabular}{clc}
\hline Parameter $^{\mathrm{a}}$ & Typical literature values & Value used in this study \\
\hline$A_{\mathrm{g}}$ & $97-100 \mathrm{pMC}$ for tritium free water & $100 \mathrm{pMC}$ \\
& $120-170 \mathrm{pMC}$ for modern water & \\
$A_{\mathrm{c}}$ & $0-3 \mathrm{pMC}$ & $0 \mathrm{pMC}$ \\
$\delta_{\mathrm{g}}$ & -20 to $-25 \%$ PDB for temperate climates & $-22 \%$ PDB \\
$\delta_{\mathrm{c}}$ & -3 to $+3 \%$ PDB & $-1 \%$ PDB \\
$\delta_{\mathrm{a}}$ & $\delta_{\mathrm{a}}=\varepsilon_{\mathrm{ag}}+\delta_{\mathrm{g}}$ & $\delta_{\mathrm{a}}=\varepsilon_{\mathrm{ag}}+\delta_{\mathrm{g}}$ \\
\hline
\end{tabular}

${ }^{a}$ See Table 2 for notation.

Table $4 \delta^{13} \mathrm{C}$ and pMC results for the TDIC in water samples taken from Permo-Triassic Sandstone and Cretaceous Chalk aquifers. Map reference numbers correspond to the identification numbers in Figure 1. Site types are specified as boreholes (B) or springs (S).

\begin{tabular}{llcccc}
\hline \multicolumn{5}{l}{} & \multicolumn{5}{c}{ Lab code } \\
Reference & Site & Type & UCD- & $\delta^{13} \mathrm{C} \pm 1 \sigma$ & $\mathrm{pMC} \pm 1 \sigma$ \\
\hline Permo-Triassic & & & & \\
1 & Belsize Road & $\mathrm{B}$ & 9768 & $-14.7 \pm 0.2$ & $58.66 \pm 0.29$ \\
2 & Glenburn & $\mathrm{B}$ & 9771 & $-14.7 \pm 0.2$ & $54.83 \pm 0.28$ \\
3 & Derriaghy & $\mathrm{B}$ & 9772 & $-15.4 \pm 0.2$ & $59.37 \pm 0.29$ \\
4 & Newforge Lane & $\mathrm{B}$ & 9774 & $-15.4 \pm 0.2$ & $55.73 \pm 0.40$ \\
5 & McAlpines \#2 & $\mathrm{B}$ & 9827 & $-15.0 \pm 0.2$ & $66.76 \pm 0.46$ \\
6 & McAlpines \#1 & $\mathrm{B}$ & 9828 & $-15.5 \pm 0.2$ & $65.61 \pm 0.46$ \\
7 & Gillilands & $\mathrm{B}$ & 9829 & $-16.6 \pm 0.2$ & $80.17 \pm 0.52$ \\
8 & Lee Jeans & $\mathrm{B}$ & 9835 & $-15.6 \pm 0.2$ & $45.72 \pm 0.33$ \\
9 & Pritchitt Foods & $\mathrm{B}$ & 9836 & $-16.3 \pm 0.2$ & $57.09 \pm 0.36$ \\
Cretaceous & & & & & \\
10 & Ligoniel & $\mathrm{S}$ & 9753 & $-17.6 \pm 0.2$ & $93.03 \pm 0.80$ \\
10 & Ligoniel & $\mathrm{S}$ & 9754 & $-17.8 \pm 0.2$ & $93.72 \pm 0.76$ \\
11 & Clendinnings & $\mathrm{B}$ & 9755 & $-15.1 \pm 0.2$ & $9.17 \pm 0.19$ \\
12 & Aughrimderg & $\mathrm{B}$ & 9756 & $-7.9 \pm 0.2$ & $7.79 \pm 0.19$ \\
13 & Toberterin & $\mathrm{S}$ & 9758 & $-15.8 \pm 0.2$ & $74.03 \pm 0.54$ \\
14 & Sounding Hill & $\mathrm{S}$ & 9760 & $-19.5 \pm 0.2$ & $87.98 \pm 0.92$ \\
15 & Wellglass & $\mathrm{S}$ & 9761 & $-19.9 \pm 0.2$ & $90.03 \pm 0.60$ \\
16 & Straidkilly & $\mathrm{S}$ & 9782 & $-17.9 \pm 0.2$ & $89.4 \pm 1.5$ \\
17 & Sallagh & $\mathrm{S}$ & 9783 & $-16.1 \pm 0.2$ & $89.1 \pm 1.0$ \\
18 & Old Pier & $\mathrm{S}$ & 9784 & $-15.6 \pm 0.2$ & $94.72 \pm 0.69$ \\
19 & The Grove & $\mathrm{S}$ & 9785 & $-19.4 \pm 0.2$ & $92.31 \pm 0.57$ \\
\hline & & & & &
\end{tabular}


Table 5 Chemistry data for groundwater sampling sites

\begin{tabular}{|c|c|c|c|c|c|c|c|c|c|c|c|}
\hline \multirow[b]{2}{*}{ Site } & \multirow{2}{*}{$\begin{array}{l}\text { Lab code } \\
\text { UCD- }\end{array}$} & \multirow[b]{2}{*}{$\mathrm{pH}$} & \multirow{2}{*}{$\begin{array}{c}\text { Temp } \\
\left({ }^{\circ} \mathrm{C}\right)\end{array}$} & \multicolumn{7}{|c|}{ Concentration $\left(\mathrm{mg} \mathrm{L}^{-1}\right)$} & \multirow[b]{2}{*}{$\delta^{18} \mathrm{O}$} \\
\hline & & & & $\mathrm{Na}^{+}$ & $\mathrm{K}^{+}$ & $\mathrm{Mg}^{2+}$ & $\mathrm{Ca}^{2+}$ & $\mathrm{HCO}_{3^{-}}$ & $\mathrm{SO}_{4}{ }^{2-}$ & $\mathrm{Cl}-$ & \\
\hline \multicolumn{12}{|l|}{ Permo-Triassic } \\
\hline Belsize Road & 9768 & 7.44 & 11.5 & 23.6 & 1.5 & 30.1 & 48.3 & 250 & 43.8 & 22 & - \\
\hline Glenburn & 9771 & 7.72 & 13.5 & 28.6 & 2 & 34.1 & 27.6 & 273 & 52 & 34 & - \\
\hline Derriaghy & 9772 & 7.48 & 15 & 22.3 & 1.6 & 30.2 & 43.4 & 173.2 & 70 & 33.5 & - \\
\hline Newforge & 9774 & 7.90 & 10.4 & 30 & 3.6 & 27 & 47.2 & 234.1 & 41 & 25.5 & - \\
\hline McAlpines \#2 & 9827 & 7.30 & 10.5 & 18.6 & 4.3 & 29.6 & 62 & 202 & 40.8 & 29.6 & - \\
\hline McAlpines \#1 & 9828 & 7.74 & 10.9 & 20.6 & 1.6 & 25.7 & 55.1 & 175 & 35.8 & 50.6 & - \\
\hline Gillilands & 9829 & 7.48 & 10.7 & 22 & 1.8 & 28.3 & 63.2 & 202 & 40.8 & 52.1 & - \\
\hline Lee Jeans & 9835 & 8.13 & 11.5 & 23.2 & 2 & 16.1 & 14.5 & 178 & 12 & 19 & - \\
\hline Pritchitt Foods & 9836 & 7.86 & 11.8 & 19 & 2 & 27.1 & 38.4 & 232 & 29 & 23.5 & - \\
\hline Ligoniel & $\begin{array}{l}9753 \\
9754\end{array}$ & 7.19 & 8.6 & 14 & 0.8 & 18 & 46 & 215.9 & 20.1 & 13.6 & -7.12 \\
\hline \multicolumn{12}{|l|}{ Cretaceous } \\
\hline Clendinnings & 9755 & 7.63 & 12.9 & 56 & 1.9 & 21 & 42 & 219.9 & 85.9 & 60.1 & -6.83 \\
\hline Aughrimderg & 9756 & 9.14 & 14.9 & 130 & 1.69 & 1.55 & 5.1 & 169.6 & 65.4 & 83.4 & -7.27 \\
\hline Toberterin & 9758 & 7.19 & 9.3 & 12 & 1.4 & 12.7 & 75 & 283.4 & 11.3 & 22.3 & -6.64 \\
\hline Sounding Hill & 9760 & 7.27 & 8.8 & 9.8 & 0.7 & 21 & 38 & 179.3 & 12.3 & 16.7 & -7.01 \\
\hline Wellglass & 9761 & 7.32 & 9.2 & 14 & 0.44 & 15.1 & 36.3 & 152.2 & 8.8 & 21.6 & -7.12 \\
\hline Straidkilly & 9782 & 7.91 & 8.7 & 13 & 0.46 & 12 & 42.4 & 154.0 & 12.6 & 27.7 & -6.74 \\
\hline Sallagh & 9783 & 7.08 & 8.8 & 10 & 0.23 & 5.7 & 33.2 & 125.9 & 8.8 & 14.2 & - \\
\hline Old Pier & 9784 & 6.94 & 9.1 & 16 & 0.9 & 9.5 & 43.0 & 173.8 & 9.0 & 25.5 & - \\
\hline The Grove & 9785 & 7.77 & 9.4 & 16 & 0.6 & 12 & 35 & 172 & 11.18 & 23.3 & - \\
\hline
\end{tabular}

phase and the excessive pMC values (ranging from 157 to 504\% for Mook and 116 to $167 \%$ for IAEA) indicate that solid phase exchange dominates the systems. These models were, therefore, deemed unsuitable in the scenarios under investigation.

There is close agreement between $A_{\mathrm{o}}$ estimates from the Pearson, F\&G, Evans, and Mass Balance models, while the Eichinger model produces results which are marginally lower. The Pearson model has been shown in other studies to account for incomplete isotopic exchange processes (Fontes and Garnier 1979) and in this study gave results which are in good agreement with models more specifically designed to deal with isotopic exchange with the solid phase. The Evans model is one such model and appears to give reasonable results for our data.

When calculating the $\mathrm{F} \& \mathrm{G}$ model, the $k(\mathrm{~F} \& \mathrm{G})$ value (Fontes 1992) initially indicated that gas phase exchange dominated the systems under investigation (with the exception of the Aughrimderg site). This finding is at variance with the other models, which predict that solid phase exchange dominates the systems. Repeating the calculation, this time correcting for solid phase isotopic exchange, produces results that are in much closer agreement with the other models.

The Mass Balance model uses extensive water chemistry and isotopic data to identify the main reactions affecting the chemical evolution of the water. It provides the most complete analysis of all the models and, therefore, one might assume, produces the best estimates for the initial activity. Nevertheless, the results of the Pearson, F\&G, Evans, and Eichinger models for the Permo-Triassic sites closely correspond with the Mass Balance estimates.

The Tamers model generally gave the lowest estimates of all the models. It is known that this model does not correct for isotopic exchange and that it may produce unreliable results when exchange reactions become significant (Fontes 1992). 
Table 6 Initial activity (as pMC) of water samples, calculated using selected hydrochemical models. The F\&G model was calculated to correct for solid phase exchange.

\begin{tabular}{llcccccc}
\hline & $\begin{array}{l}\text { Lab code } \\
\text { UCD- }\end{array}$ & Tamers & Pearson & F\&G & Evans & Eichinger & $\begin{array}{c}\text { Mass } \\
\text { balance }\end{array}$ \\
\hline Permo-Triassic & & & & & & & \\
Belsize Road & 9768 & 54.3 & 65.2 & 65.4 & 64.9 & 62.7 & 65.2 \\
Glenburn & 9771 & 52.3 & 65.2 & 65.4 & 64.7 & 62.7 & 64.8 \\
Derriaghy & 9772 & 53.7 & 68.6 & 68.9 & 67.9 & 66.4 & 68.6 \\
Newforge Lane & 9774 & 51.6 & 68.3 & 68.5 & 68.1 & 65.5 & 68.9 \\
McAlpines \#2 & 9827 & 56.7 & 66.7 & 66.8 & 66.4 & 64.2 & N/A \\
McAlpines \#1 & 9828 & 52.3 & 69.0 & 69.2 & 68.7 & 66.3 & N/A \\
Gillilands & 9829 & 54.0 & 74.2 & 74.4 & 74.0 & 72.0 & N/A \\
Lee Jeans & 9835 & 50.8 & 69.6 & 69.8 & 69.2 & 66.6 & 70.5 \\
Pritchitt Foods & 9836 & 51.6 & 72.8 & 73.0 & 72.4 & 70.0 & 73.9 \\
Cretaceous & & & & & & & \\
Ligoniel & 9753 & 57.6 & 79.9 & 79.9 & 79.8 & 78.6 & N/A \\
Ligoniel & 9754 & 57.6 & 79.0 & 79.0 & 78.9 & 77.6 & N/A \\
Clendinnings & 9755 & 52.8 & 67.0 & 67.3 & 66.6 & 64.6 & 67.1 \\
Aughrimderg & 9756 & 50.1 & 32.9 & 32.5 & 31.5 & 30.5 & 28.6 \\
Toberterin & 9758 & 57.5 & 70.4 & 70.5 & 70.2 & 68.3 & N/A \\
Sounding Hill & 9760 & 56.5 & 88.1 & 88.2 & 88.0 & 87.3 & N/A \\
Wellglass & 9761 & 55.8 & 89.9 & 90.0 & 89.8 & 88.9 & N/A \\
Straidkilly & 9782 & 51.7 & 80.6 & 80.7 & 80.5 & 77.4 & N/A \\
Sallagh & 9783 & 59.5 & 72.0 & 72.1 & 71.9 & 70.1 & N/A \\
Old Pier & 9784 & 62.1 & 69.5 & 69.5 & 69.3 & 66.9 & N/A \\
The Grove & 9785 & 52.2 & 87.5 & 87.7 & 87.5 & 84.7 & N/A \\
\hline
\end{tabular}

${ }^{\mathrm{a}} \mathrm{N} / \mathrm{A}=$ data not available.

Our data are in broad agreement with the validation studies of Fontes and Garnier (1979), and Fontes (1992) in highlighting the need for detailed hydrochemical and hydrogeological knowledge of a groundwater system before selecting an appropriate model.

\section{Age Estimations}

Initial activities were estimated using the models and the ages of the waters calculated:

$$
\operatorname{Age}(y r)=-\frac{t_{1 / 2}}{\ln 2} \ln \left(\frac{A_{T}}{A_{o}}\right)
$$

where $t_{1 / 2}$ is the ${ }^{14} \mathrm{C}$ half-life (5730 yr) and $A_{\mathrm{T}}$ is the measured activity of the TDIC as a pMC.

Table 7 presents age estimates for all sites corresponding with the pMC data of Table 6 . The age values for water samples taken from the Permo-Triassic aquifers range from "post-bomb" or modern (Gillilands borehole) to approximately 3500 BP (Lee Jeans borehole). Water samples from the Cretaceous aquifers, range from "post-bomb" for all spring sources to approximately 16,500 BP for the Clendinnings borehole. 
Both boreholes in the Cretaceous Chalk yielded water samples that were clearly ancient. Despite the higher ${ }^{14} \mathrm{C}$ activity of the Clendinnings sample relative to the Aughrimderg sample, the models indicate that the water from the former is older. However, $\delta^{18} \mathrm{O}$ analysis of the Clendinnings water gave a value of $-6.8 \%$ o with respect to $\mathrm{SMOW}^{3}$ (standard mean ocean water), a value indicative of postglacial times (see Fontes and Garnier 1979). The $\delta^{18} \mathrm{O}$ value suggests that the water is certainly younger than 15,000 yr old and probably younger than about 12,000 yr old. Further isotopic and chemical analyses of the waters and substrates are necessary to resolve the apparent inconsistency. Similarly, the $\delta^{18} \mathrm{O}$ measurement for the Aughrimderg site ( $-7.3 \%$ with respect to SMOW) suggests an age of less than $12,000 \mathrm{yr}$, which, in this case, is consistent with the age estimates derived from the models.

Springs in the Cretaceous Chalk were shown to yield waters that were modern or "post-bomb". These data are in good agreement with the work carried out by Barnes (1999) in which groundwater was shown to have rapid recharge and flow in the Cretaceous Chalk areas along the northeast coast of Northern Ireland.

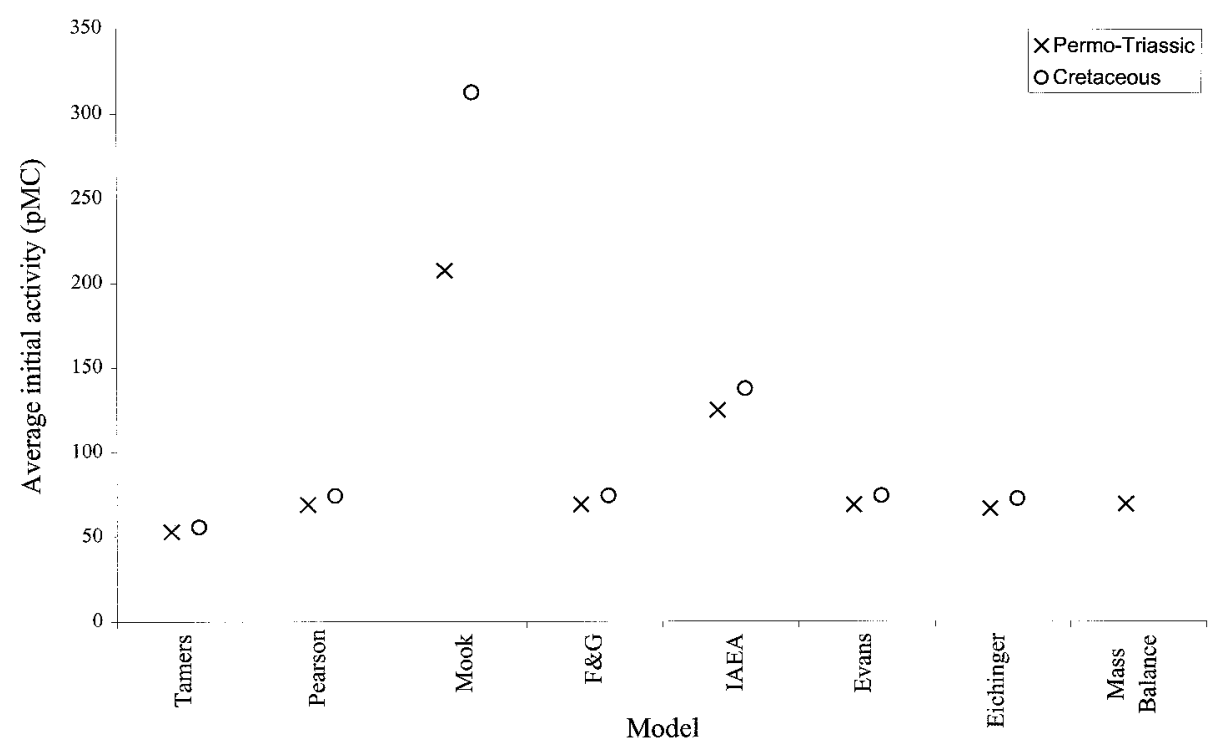

Figure 3 Average initial activity (as pMC) returned by each model for samples taken from the Permo-Triassic and Cretaceous aquifers

\section{Sensitivity Analysis}

Sensitivity analysis was carried out to investigate variations in model output arising from changes in the values of parameters used in the models. All models were first run using an initial set of parameter values (Table 8). A single parameter was then selected and its initial value was changed by either $+2 \sigma$ or to the upper extreme value from the literature (Table 3 ). All other parameters were maintained at their initial values. The output of each model was calculated. The same parameter was then varied by either $-2 \sigma$ from its initial value or to the lower extreme value from the literature, and 
the output recalculated. A comparative evaluation of the sensitivity of the models to input parameter variations was carried out and calculated as:

$$
S=\frac{R_{\max }-R_{\min }}{R_{\max }}
$$

where $R_{\max }$ and $R_{\min }$ are the outputs for the two calculations and $R_{\max }>R_{\min }$.

A value of 0 indicates that the model is not sensitive to the parameter change, while a value approaching 1 indicates the model is highly sensitive to the parameter change. This procedure was repeated for each parameter in turn, and the results are presented in Table 9.

The analysis clearly shows that the most sensitive parameters controlling model output values are the ${ }^{13} \mathrm{C}$ content of the TDIC, soil $\mathrm{CO}_{2}$ and solid carbonates: $\delta_{\mathrm{g}}>\delta_{\mathrm{c}}>\delta_{\mathrm{T}}$ (in order of decreasing sensitivity). The Mook model showed exceptional sensitivity to all parameters relative to the other models. This is probably related to the fact that this model is specifically designed to correct for gasphase exchange, while the fixed parameter values used in our analysis were more characteristic of a solid-phase exchange system. For the same reason, the $S$ value for $\delta_{\mathrm{c}}$ of the Mook model returned a value greater than unity.

Table 7 Ages of water samples (in years BP), as calculated using selected hydrochemical models. The F\&G model was calculated to correct for solid-phase exchange.

\begin{tabular}{lcrrrrrr}
\hline Site & $\begin{array}{c}\text { Lab code } \\
\text { UCD- }\end{array}$ & Tamers & Pearson & F\&G & Evans & Eichinger & $\begin{array}{l}\text { Mass } \\
\text { balance }\end{array}$ \\
\hline Permo-Triassic & & & & & & & \\
Belsize Road & 9768 & -641 & 880 & 890 & 830 & 550 & 870 \\
Glenburn & 9771 & -400 & 1440 & 1460 & 1370 & 1110 & 1380 \\
Derriaghy & 9772 & -840 & 1190 & 1220 & 1110 & 920 & 1190 \\
Newforge Lane & 9774 & -630 & 1690 & 1710 & 1660 & 1340 & 1750 \\
McAlpines \#2 & 9827 & -1360 & -10 & 0 & -50 & -320 & N/A \\
McAlpines \#1 & 9828 & -1880 & 420 & 440 & 380 & 90 & N/A \\
Gillilands & 9829 & -3270 & -640 & -620 & -670 & -890 & N/A \\
Lee Jeans & 9835 & 870 & 3470 & 3500 & 3430 & 3110 & 3580 \\
Pritchitt Foods & 9836 & -841 & 2010 & 2030 & 1970 & 1690 & 2130 \\
Cretaceous & & & & & & & \\
Ligoniel & 9753 & -3960 & -1260 & -1250 & -1270 & -1390 & N/A \\
Ligoniel & 9754 & -4020 & -1420 & -1410 & -1430 & -1560 & N/A \\
Clendinnings & 9755 & 14,500 & 16,400 & 16,500 & 16,400 & 16,100 & 16,500 \\
Aughrimderg & 9756 & 15,400 & 11,900 & 11,800 & 11,600 & 11,300 & 10,800 \\
Toberterin & 9758 & -2100 & -420 & -410 & -440 & -670 & N/A \\
Sounding Hill & 9760 & -3660 & 10 & 20 & 10 & -70 & N/A \\
Wellglass & 9761 & -3950 & -20 & 0 & -20 & -100 & N/A \\
Straidkilly & 9782 & -4540 & -860 & -850 & -870 & -1190 & N/A \\
Sallagh & 9783 & -3340 & -1760 & -1750 & -1770 & -1980 & N/A \\
Old Pier & 9784 & -3490 & -2560 & -2560 & -2580 & -2880 & N/A \\
The Grove & 9785 & -4710 & -440 & -420 & -450 & -710 & N/A \\
\hline
\end{tabular}


Table 8 Initial parameter values used in sensitivity analysis

\begin{tabular}{cl}
\hline Parameter & Initial value \\
\hline $\mathrm{a}$ & $0.71 \mathrm{mmol} \mathrm{kg}^{-1}$ \\
$\mathrm{~b}$ & $2.95 \mathrm{mmol} \mathrm{kg}^{-1}$ \\
$A_{\mathrm{g}}$ & $100 \mathrm{pMC}$ \\
$A_{\mathrm{c}}$ & $2 \mathrm{pMC}$ \\
$\delta_{\mathrm{T}}$ & $-10.90 \% \mathrm{PDB}$ \\
$\delta_{\mathrm{g}}$ & $-22 \% \circ \mathrm{PDB}$ \\
$\delta_{\mathrm{c}}$ & $+2.35 \%$ PDB \\
$\mathrm{T}$ & $282 \mathrm{~K}$ \\
\hline
\end{tabular}

Table 9 Sensitivity of models to changes in parameter values (upper extreme value in brackets)

\begin{tabular}{llllllll}
\hline Values & Tamers & Pearson & Mook & F\&G & IAEA & Evans & Eichinger \\
\hline$a=0.695(0.725)$ & 0.005 & n.p. & 0.038 & 0.000 & 0.000 & n.p. & 0.002 \\
$b=2.85(3.05)$ & 0.009 & n.p. & 0.058 & 0.000 & 0.000 & n.p. & 0.003 \\
$A_{\mathrm{g}}=97(100)$ & 0.030 & 0.030 & 0.029 & 0.030 & 0.030 & 0.030 & 0.024 \\
$A_{\mathrm{c}}=0(3)$ & 0.020 & 0.025 & 0.057 & 0.025 & 0.003 & n.p. & 0.020 \\
$\delta_{\mathrm{T}}=-10.5(-11.3)$ & n.p. $^{\mathrm{a}}$ & 0.057 & 0.377 & 0.057 & 0.057 & 0.059 & 0.070 \\
$\delta_{\mathrm{g}}=-20(-25)$ & n.p. & 0.177 & 0.613 & 0.177 & 0.278 & 0.183 & 0.202 \\
$\delta_{\mathrm{c}}=-1(3)$ & n.p. & 0.147 & $>1^{\mathrm{b}}$ & 0.147 & 0.034 & 0.154 & 0.199 \\
$T=281(283)$ & n.p. & n.p. & 0.071 & 0.000 & 0.016 & 0.003 & 0.000 \\
\hline
\end{tabular}

${ }^{a}$ n.p. = not a parameter used in the model in question.

${ }^{b}$ Negative output for $\mathrm{R}_{\min }$

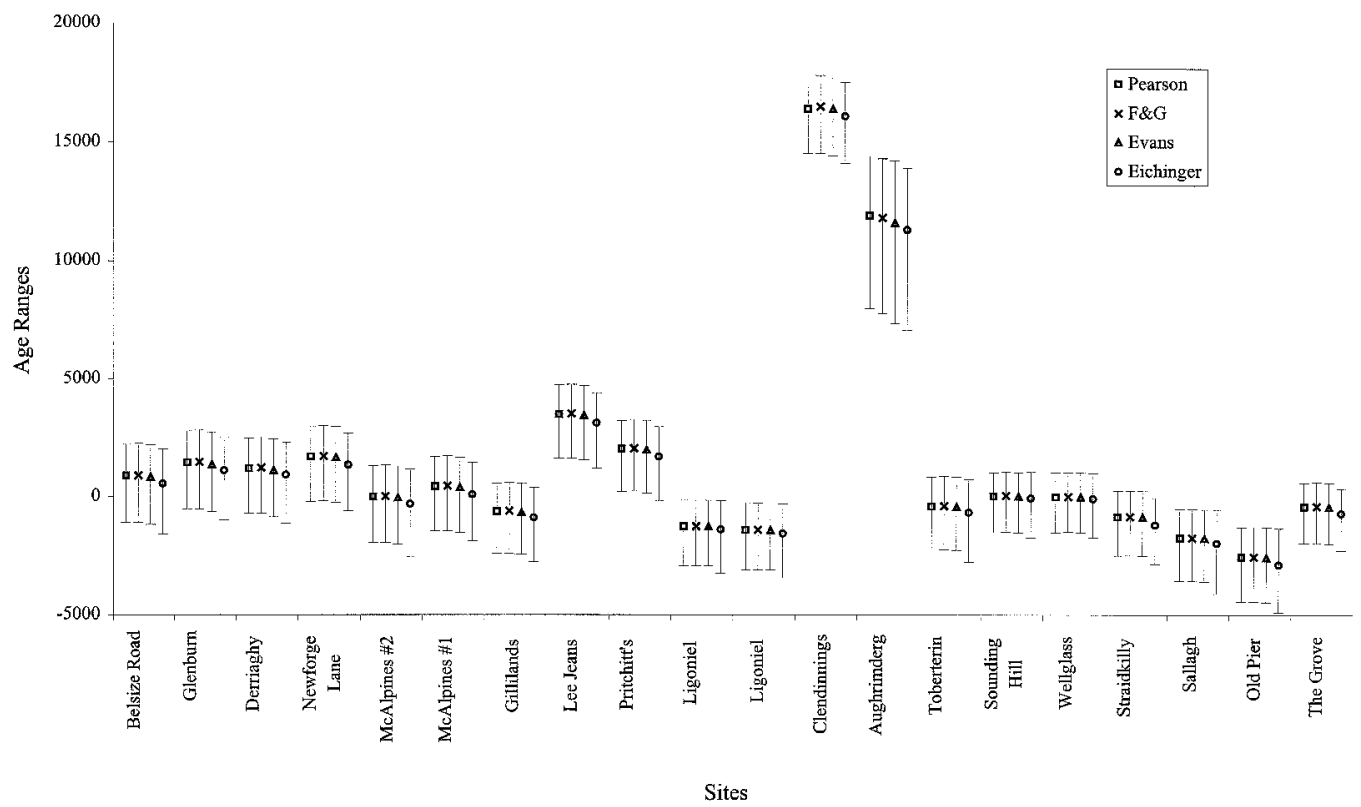

Figure 4 Results of error analysis applied to groundwater age estimation 


\section{Error Analysis}

Error analysis was conducted on the Pearson, F\&G, Evans, and Eichinger models. As shown above, these models are very sensitive to changes in the $\delta^{13} \mathrm{C}$ values for the solid carbonates $\left(\delta_{\mathrm{c}}\right)$, soil $\mathrm{CO}_{2}$ $\left(\delta_{\mathrm{g}}\right)$, and total dissolved inorganic carbon $\left(\delta_{\mathrm{T}}\right)$. With this in mind, the errors on the ${ }^{14} \mathrm{C}$ ages were estimated using combinations of the upper and lower limits of these values (Table 3 ) and the maximum potential age range for each sample was estimated. The error in measuring the pMC was presumed negligible relative to the error in calculating $A_{\mathrm{o}}$ from the models. As Figure 4 shows, the uncertainties in the ages are in some cases greater than the age itself, demonstrating the imprecision associated with the application of these procedures. The uncertainties could undoubtedly be reduced with a better knowledge of the groundwater system. In particular, $\delta_{\mathrm{g}}$ and $\delta_{\mathrm{c}}$ could be measured instead of being estimated, and thereby more tightly constraining the age.

\section{CONCLUSION}

Data for waters from Permo-Triassic and the Cretaceous Chalk aquifers were input to a range of models, and ages of groundwaters were estimated. Eight models were applied in our study, and the work includes a comparative examination of their relative merits. Results indicate that the Tamers, Mook, and IAEA models gave anomalous ages because of their inability to correct for solid-phase isotopic exchange (which appeared to be the dominant exchange mechanism at all locations). Despite differing approaches to model derivation, the Pearson, F\&G, Evans, Eichinger, and Mass Balance models produced results that were in broad agreement for all waters samples.

The analysis revealed that water taken from boreholes tended to be older than that from spring wells. Despite the apparent rapid throughput one might associate with an exceptionally wet climate, our work shows that there are sources of ancient groundwater in Ireland. A borehole in County Tyrone produced water dating to between 7000 and 14,000 BP. Another in County Armagh yielded water that dated to between 14,000 and 18,000 BP. However, stable oxygen isotopic analysis $\left(\delta^{18} \mathrm{O}\right)$ suggests that this is an overestimate of the age of the water and points to an upper age limit of about 12,000 yr. Water samples from boreholes in Permo-Triassic substrates returned dates between around 800 to $4000 \mathrm{BP}$.

Of all the sites investigated, the spring wells along the chalk-basalt boundary of the northeast Antrim coastline show the most rapid recharge and flow, and, hence, the greatest potential for contamination from surface runoff. Many samples from these locations produced negative ages, indicating the presence of ${ }^{14} \mathrm{C}$ derived from atmospheric testing of nuclear weapons.

Error analysis was carried out on the Pearson, F\&G, Evans, and Eichinger models for all sites to account for uncertainties in the $\delta^{13} \mathrm{C}$ values used in calculating the models. Sensitivity analysis showed the models to be most susceptible to changes in the $\delta^{13} \mathrm{C}$ values for the solid carbonates $\left(\delta_{\mathrm{c}}\right)$, soil $\mathrm{CO}_{2}\left(\delta_{\mathrm{g}}\right)$, and TDIC $\left(\delta_{\mathrm{T}}\right)$.

Our data demonstrate the considerable uncertainty associated with estimating the age of groundwaters using ${ }^{14} \mathrm{C}$-based methodologies. Despite the inexact nature of the technique, in many circumstances it is the only means of groundwater dating. However, this is a relatively new discipline in which we model complex chemical interactions, and most of the models demand extensive knowledge of aquifer geochemistry for effective use. As geochemical databases for our aquifers improve, and measurements of isotopic ratios for the soil $\mathrm{CO}_{2}$ and solid carbonates become available, more precise and accurate age estimation will be possible. 


\section{ACKNOWLEDGMENTS}

Our sincere thanks to many people who gave assistance during the course of this work. Enterprise Ireland and the Department of the Environment (Northern Ireland) provided the necessary finance for the project. Dr Neil Ogle kindly carried out the stable isotope analysis. Thanks to Bart Fannin, David Cooney and all the staff of the Technical Workshops of the UCD Physics Department. Dr Stephen Barnes and Deirdre Gibbons helped on sampling expeditions and provided much supporting data. The Water Executive of Northern Ireland provided encouragement, access to sites and technical information. Our thanks also to all the industries and individuals who gave us access to their water sources.

\section{REFERENCES}

Barnes S. 1999. Karstic groundwater flow characteristics in the Cretaceous Chalk aquifer, Northern Ireland. Quarterly Journal of Engineering Geology 32:55-68.

Barnes S, and Worden R H. 1998. Understanding groundwater sources and movement using water chemistry and tracers in a low matrix permeability terrain: the Cretaceous (Chalk) Ulster white limestone formation, Northern Ireland. Applied Geochemistry 13:143-153.

Bennett JRP. 1975. The Lagan Valley hydrogeological study. Geological Survey for Northern Ireland. Open file report N. 57.

Eichinger L. 1983. A contribution to the interpretation of ${ }^{14} \mathrm{C}$ groundwater ages considering the example of a partially confined sandstone aquifer. Radiocarbon 25(2):347-356.

Evans GV, Otlet RL, Downing A, Monkhouse RA, Rae G. 1979. Some problems in the interpretation of isotope measurements in United Kingdom aquifers. Isotope Hydrology II. Vienna: IAEA. p 679-708.

Fontes JC. 1983. Dating of groundwater. Guidebook on Nuclear techniques in hydrology. Vienna: IAEA. $\mathrm{p}$ 285-317.

Fontes JC. 1992. Chemical and isotopic constraints on ${ }^{14} \mathrm{C}$ dating of groundwater. In: Taylor RE, Long A, Kra RS, editors. Radiocarbon dating after four decades: an interdisciplinary perspective. New York: SpringerVerlag. p 242-61.

Fontes JC, Garnier JM. 1979. Determination of the initial ${ }^{14} \mathrm{C}$ activity of the total dissolved carbon: a review of the existing models and a new approach. Water Resources Research 15(2):399-413.

Ingerson E, Pearson FJ. 1964. Estimation of age and rate of motion of groundwater by the ${ }^{14} \mathrm{C}$ method. In: Miyake Y, Koyama T, editors. Recent researches in the field of hydrosphere, atmosphere and nuclear geochemistry. Tokyo: Maruzen. p 263-83. 